\title{
Prediktor Kejadian TB pada ODHA di Salah Satu RS Pemerintah Bogor, Tahun 2014-2016
}

\author{
Predictors of TB among PLWH in One of Bogor \\ Government Hospital, 2014-2016
}

\author{
Ulya Qoulan Karimaa ${ }^{a}$, Mondastri Korib Sudaryo ${ }^{b}$, Nuning Maria Kiptiyah ${ }^{b}$ \\ aProgram Magister Epidemiologi, Fakultas Kesehatan Masyarakat, Universitas Indonesia \\ 'Departemen Epidemiologi, Fakultas Kesehatan Masyarakat, Universitas Indonesia
}

\section{A B S TRAK}

TB merupakan tantangan bagi pengendalian Acquired Immunodeficiency Syndrome (AIDS) karena merupakan infeksi oportunistik terbanyak pada orang dengan HIV/AIDS (ODHA). TB dapat meningkatkan progresivitas HIV dan meningkatkan risiko kematian bagi penderita HIV. Tujuan penelitian ini adalah untuk mengetahui prediktor yang berhubungan dengan kejadian TB pada ODHA di salah satu RS tahun 2014-2016. Desain studi yang digunakan adalah cross sectiona/dengan menggunakan data register ART dan Rekam Medis. Sampel berjumlah 817 pasien HIV. Analisis data dilakukan dengan menggunakan multiple cox regression. Hasil analisis multivariat menunjukkan adanya peningkatan risiko TB pada kelompok dengan anemia (PR=1,54,95\% CI: 1,17-2,03) dibandingkan kelompok tanpa anemia, adanya status IO ( $P R=5,9,95 \%$ CI: 2,92-11,91) dibandingkan kelompok tanpa IO, stadium HIV 3-4 (PR=8,794, 95\% CI: 4,54-17,00) dibandingkan stadium HIV 1-2. Selain itu ditemukan adanya interaksi antara variabel stadium HIV dan status IO. Perlu adanya perhatian khusus kepada ODHA dengan anemia, infeksi oportunis, dan stadium HIV lanjut (3-4) serta perlu perhatian khusus kepada ODHA dengan stadium HIV awal (1-2) tetapi disertai dengan infeksi oportunis

Kata kunci: Bogor, cross sectional, HIV/AIDS, prediktor, TB

\section{A B S TR A C T}

TB is a challenge for the control of Acquired Immunodeficiency Syndrome (AIDS) because it is the most common opportunistic infection in people living with with HIV (PLWH). TB increase HIV progressivity and increase the risk of death for PLWH. The purpose of this study is to determine the predictors are associated with TB among PLWH in one of Bogor Government Hos pital, 2014-2016. Study design was cross sectional using ART register data and Medical Record. Total sample of 817 HIV patients were collected. Multiple cox regression analysis were applied in this research. The results of multivariate analysis showed an increased risk of TB in the group with anemia (PR $=1.54,95 \%$ CI: 1.17-2.03) compared to the group without anemia, the status of IO (PR $=5.9,95 \%$ CI: 2,92-11,91) than those without IO, HIV stage 3-4 (PR = 8,794, 95\% CI: 4.54-17,00) than HIV 1-2 stage. In addition, there was an interaction between HIV stage and IO. There is need to give more attention regarding the factors associated with TB among PLWH i.e. anemia, opportunistic infections, and advanced HIV stadium (3-4) and more attention to PLWH with early HIV stages (1-2) but with opportunistic infections.

Key words: Bogor, cross sectional, HIV / AIDS, Predictors, TB

diagnosis dan terapi TB. ${ }^{1}$

Pada tahun 2014, diperkirakan sebanyak 1,2 juta (12\%) dari 9,6 juta orang yang terkena TB, adalah HIV positif. Orang dengan HIV 26 kali lebih mungkin untuk mendapat TB dibandingkan dengan orang tanpa HIV positif. Epidemi HIV menyebabkan peningkatan drastis dalam kasus-kasus TB dan kematian TB di banyak negara. ${ }^{2}$

Di Indonesia menurut data Kementerian Kesehatan RI hingga akhir Desember 2010 secara kumulatifjumlah kasus AIDS yang dilaporkan berjumlah 24.131 kasus dengan infeksi penyerta terbanyak adalah TB yaitu sebesar 11.835 kasus (49\%). ${ }^{1}$

HIV tidak hanya membuat diagnosis TB menjadi sulit, tetapi juga meningkatkan insidens TB. Angka *Korespondensi: Ulya Qoulan Karima, Program Magister Epidemiologi, Fakultas Kesehatan Masyarakat, UniversitasIndonesia; Email: ulyaqoulankarima@gmail.com 
kejadian TB lebih besar pada orang dengan HIV dibandingkan pada orang tanpa HIV. ${ }^{3}$

Dibandingkan dengan orang tanpa HIV, ODHA mempunyai risiko 20 kali untuk menderita TB dan risiko ini akan terus meningkat seiring dengan kadar CD4 yang menurun secara drastik. ${ }^{4}$

Menurut Uyainah, A (2009), koinfeksi TB menjadi masalah di karena beberapa hal seperti jumlah kasus di Indonesia yang tinggi sehingga meningkatkan risiko kontak dgn pasien HIV, TB pada pasien HIV meningkatkan risiko kematian dan merupakan penyebab kematian utama bagi penderita HIV, TB meningkatkan progresivitas HIV sebagai berikut: ${ }^{5}$

a. Penderita TB dengan HIV sering mempunyai viral loads HIV yang tinggi

b. Penurunan imunitas lebih cepat dan pertahanan hidup bisa lebih singkat walaupun pengobatan TB berhasil

c. Penderita TB HIV mempunyai kemungkinan hidup lebih singkat dibanding penderita HIV yang tidak pernah terkena TB

Studi yang dilakukan oleh Aghnia Jolanda Putri menyimpulkan bahwa infeksi oportunistik utama yang menyebabkan kematian pada penyandang AIDS di RS Dr. M. Djamil Padang pada tahun 2010-2012 adalah gangguan sistem respirasi seperti bronkopneumonia dan tuberculosis. ${ }^{6}$

Rumah Sakit Pusat Rujukan bagi ODHA di Jawab Barat yang memberikan pelayanan ART (Keputusan Menteri Kesehatan RI Nomor 760/MENKES/SK/VI/ 2007). Data jumlah pasien HIV secara kumulatif di RS tersebut dari tahun 2007-2017 sebanyak 2.628 pasien. Pola infeksi oportunistik menunjukkan bahwa kejadian TB secara kumulatif dari tahun 2007-2016 sebanyak 1.756 pasien. Selain itu kebijakan nasional kolaborasi TB-HIV mulai melaksanakan praktik pemberian Isoniazid Preventive Therapy (IPT) atau Program Pencegahan dengan INH (PP INH) tahun 2012 pada ODHA salah satunya dimulai di RS tersebut.

Sehingga rumusan masalah dalam penelitian ini adalah TB merupakan infeksi penyerta yang sering terjadi pada ODHA, TB akan meningkatkan progresivitas HIV dan meningkatkan risiko kematian bagi penderita HIV, serta belum diketahuinya prediktor kejadian TB pada ODHA di Bogor t ahun 2014-2016.

\section{Metode Penelitian}

Desain studi yang digunakan dalam penelitian tahun. Kriteria eksklusi adalah data mengenai status TB tidak lengkap ini adalah cross sectional untuk mengetahui faktor apa saja yang berhubungan kejadian TB pada ODHA. Pengumpulan data berlangsung dari bulan Mei-Juni 2017 di Poli NAPZA dan Unit Rekam Medis Populasi dalam penelitian ini adalah seluruh pasien HIV/AIDS yang terdaftar dan dirawat tahun 2014-2016. Semua pasien pada populasi eligibleyang memenuhi kriteria inklusi dan eksklusi. Kriteria inklusi yaitu berusia $\geq 15$ tahun. Kriteria eksklusi adalah data mengenai status TB tidak lengkap.

Pada outcome yaitu TB, status TB yang dimaksud adalah status TB yang merupakan hasil skrining pada saat kunjungan pertama. Sementara pada exposure seperti status gizi (diukur dengan menggunakan IMT), status anemia (diukur dengan menggunakan kadar Hb), Anti Retroviral Theraphy (ART), PP INH, Infeksi Oportunis (IO), stadium HIV, dan kadar CD4, juga merupakan variabel yang pengukurannya dilakukan pada saat kunjungan pertama. Selain itu, dilakukan juga penilaian terhadap variabel sosial demografi seperti umur, jenis kelamin, tingkat pendidikan, pekerjaan, dan status pernikahan. Jumlah sampel dihitung menggunaan rumus besar sampel untuk pengujian hipotesis beda dua proporsi (Kelsey, 1996). ${ }^{7}$ Dengan $\alpha$ error $=0,05$ dan power $=0,80$, jumlah sampel minimal adalah 208 . Sumber data berasal dari register ART di Poli NAPZA dan unit Rekam Medis. Dari pendataan register ART di Poli NAPZA, didapatkan daftar seluruh pasien HIV yang berobat dari tahun 2007-2017. Dari daftar tersebut kemudian dipilih responden yang akan menjadi sampel. Karena dalam penelitian ini metode sampling adalah dengan total sampling, maka seluruh pasien HIV dari tahun 2014-2016 dipilih.

Dalam register ART terdapat informasi yang cukup lengkap mengenai beberapa variabel yaitu hasil skrining TB (dengan tanggalnya), tanggal konfirmasi status HIV, umur, jenis kelamin, pendidikan, jenis pekerjaan, status pernikahan, berat badan, tinggi badan, pemberian ART, Infeksi Oportunis, stadium HIV, dan kadar CD4. Karena ada beberapa variabel yang datanya tidak ada dalam register tersebut, maka dilakukan penelusuran dan konfirmasi data melalui rekam medik.

Dari total sampel sebanyak 817, beberapa variabel mengalami missing. Missing data tertinggi pada variabel kadar CD4 yaitu 313 subjek, kemudian diikuti oleh kadar Hb sebesar 230 subjek, IMT sebesar 66 subjek, IO sebesar 61 subjek, stadium sebesar 40 subjek, faktor risiko sebesar 35 subjek, status 
pernikahan sebesar 10 subjek. Sehingga total data yang paling lengkap adalah 374 subjek yang dianalisis pada tahap multivariat. Sedangkan pada tahap univariat dan bivariat menggunakan seluruh data yang tersedia pada masing-masing variabel.

Analisis data dalam penelitian ini menggunakan software SPSS 20.0 for windows. ${ }^{8}$ Analisis data dilakukan dengan multiple cox regression. Penelitian ini telah melalui prosedur kaji etik oleh Komite Etik Riset dan Pengabdian Kesehatan Masyarakat Fakultas Kesehatan Masyarakat Universitas Indonesia dan dinyatakan lolos kaji etik dengan Nomor Surat: 293/UN2.F10/ PPM.00.02/2017.

\section{Hasil}

Berdasarkan Tabel.1, Proporsi kasus TB dalam penelitian ini adalah sebesar 54\%. Dari 441 kasus TB yang ada, hanya 270 yang mempunyai infomasi mengenai lokasi TB, yaitu sebagian besar $(90,4 \%)$ merupakan kasus TB paru saja. Dari 441 kasus TB yang ada, hanya 204 yang mempunyai informasi mengenai metode pemeriksaan TB, yaitu sebagian besar (87,3\%) dengan menggunakan radiologi.

Berdasarkan Tabel 2, kelompok umur > 35 tahun berisiko 1,12 kali (95\% CI: 0,90-1,38) untuk terkena TB dibandingkan pada kelompok umur 15-35 tahun. Kelompok laki-laki memiliki kecenderungan 0,83 kali (95\% CI: 0,69-1,01) untuk terkena TB dibandingkan pada kelompok perempuan.

Untuk tingkat pendidikan, kelompok pendidikan menengah berisiko 1,42 kali (95\% CI: 1,05-1,93) untuk terkena TB dibandingkan pada kelompok pendidikan tinggi. kelompok pendidikan rendah berisiko 1,77 kali
(95\% CI: 1,16-2,70) dibandingkan pada kelompok pendidikan tinggi. Kelompok yang tidak bekerja memiliki kecenderungan 0,94 kali (95\% CI: 0,76-1,14) untuk terkena TB dibandingkan pada kelompok yang bekerja. Kelompok yang belum menikah memiliki kecenderungan 0,80 kali (95\% CI: 0,66-0,98) untuk terkena TB dibandingkan pada kelompok yang menikah. Kelompok janda/duda memiliki kecenderungan 0,81 kali (95\% CI: 0,56-1,18) dibandingkan pada kelompok yang menikah.

Kelompok dengan IMT kurang berisiko 1,90 kali $(95 \%$ CI: 1,54-2,34) untuk terkena TB dibandingkan pada kelompok dengan IMT baik. kelompok anemia berisiko 2,46 kali (95\% CI: 1,89-3,20) untuk terkena TB dibandingkan pada kelompok yang tidak anemia.

Kelompok yang mendapatkan ART memiliki kecenderungan 0,44 kali (95\% CI: 0,36-0,53) untuk terkena TB dibandingkan pada kelompok yang tidak mendapatkan ART. Hal ini berarti bahwa pemberian ART merupakan faktor protektif terhadap TB. kelompok yang mendapatkan PP INH memiliki kecenderungan 0,42 kali (95\% CI: 0,28-0,63) untuk terkena TB dibandingkan pada kelompok yang tidak mendapatkan PP INH. Hal ini berarti bahwa pemberian PP INH merupakan faktor protektif terhadap TB.

Kelompok yang mempunyai IO berisiko 2,31 kali $(95 \%$ CI: 1,88-2,85) untuk terkena TB dibandingkan pada kelompok yang tidak mempunyai IO. kelompok dengan faktor risiko non IDU berisiko 1,27 kali (95\% CI: 0,99-1,62) untuk terkena TB dibandingkan pada kelompok dengan faktor risiko IDU. kelompok dengan stadium HIV 3-4, berisiko 4,41 kali (95\% CI: 3,32-5,88) untuk terkena TB dibandingkan pada kelompok dengan

Tabel 1. Distribusi Frekuensi Responden Berdasarkan Status TB

\begin{tabular}{lrr}
\hline \multicolumn{1}{c}{ Karakteristik Status TB } & Jum lah \\
\hline Status TB & $N$ & $\%$ \\
Ya & 441 & 54 \\
Tidak & 376 & 46 \\
Total & 817 & 100 \\
\hline Lokasi TB & & \\
Paru & 244 & 90,4 \\
Ekstra Paru & 9 & 3,3 \\
Paru dan Ekstra Paru & 17 & 6,3 \\
Total & 270 & 100 \\
\hline Pemeriksaan TB ${ }^{\text {a }}$ & & \\
Radiologi & 178 & 87,3 \\
Gejala Klinis & 12 & 5,9 \\
Dahak & 14 & 6,9 \\
Total & 204 & 100 \\
\hline
\end{tabular}

a Diantara Responden dengan Status TB positif 
Tabel 2 Hubungan Masing-Masing Variabel dengan TB

\begin{tabular}{|c|c|c|c|c|c|c|c|}
\hline \multirow{2}{*}{ Sosial Demografi } & \multicolumn{2}{|c|}{$\mathrm{TB}(+)$} & \multicolumn{2}{|c|}{ TB (-) } & \multirow{2}{*}{ Total } & \multirow{2}{*}{ PR (95\% CI) } & \multirow{2}{*}{ Nilai $p$} \\
\hline & $\mathrm{N}$ & $\%$ & $\mathrm{~N}$ & $\%$ & & & \\
\hline \multicolumn{8}{|l|}{ Umur } \\
\hline 15-35 Tahun & 317 & 52,3 & 289 & 47,7 & 606 & 1 & \\
\hline > 35 Tahun & 124 & 58,8 & 87 & 41,2 & 211 & $1,12(0,90-1,38)$ & 0,304 \\
\hline \multicolumn{8}{|l|}{ Jenis Kelamin } \\
\hline Perempuan & 156 & 60,9 & 100 & 39,1 & 256 & 1 & \\
\hline Laki-Laki & 285 & 50,8 & 276 & 49,2 & 561 & $0,83(0,69-1,01)$ & 0,068 \\
\hline \multicolumn{8}{|l|}{ Tingkat Pendidikan ${ }^{a}$} \\
\hline Tinggi & 46 & 39,0 & 72 & 61,0 & 118 & 1 & \\
\hline Menengah & 355 & 55,5 & 285 & 44,5 & 640 & $1,42(1,05-1,93)$ & 0,024 \\
\hline Dasar & 40 & 69,0 & 18 & 31,0 & 58 & $1,77(1,16-2,70)$ & 0,008 \\
\hline \multicolumn{8}{|l|}{ Pekerjaan $^{a}$} \\
\hline Bekerja & 137 & 56,6 & 105 & 43,4 & 242 & 1 & \\
\hline Tidak Bekerja & 304 & 53,0 & 270 & 47,0 & 574 & $0,94(0,76-1,14)$ & 0,517 \\
\hline \multicolumn{8}{|l|}{ Status Pernikahan } \\
\hline Menikah & 238 & 59,6 & 161 & 40,4 & 399 & 1 & \\
\hline Belum Menikah & 165 & 48,0 & 179 & 52,0 & 344 & $0,80(0,66-0,98)$ & 0,031 \\
\hline Janda/Duda & 31 & 48,4 & 33 & 51,6 & 64 & $0,81(0,56-1,18)$ & 0,276 \\
\hline \multicolumn{8}{|l|}{ Karakteristik Gizi } \\
\hline \multicolumn{8}{|l|}{ Status Gizi ${ }^{c}$} \\
\hline Baik & 127 & 36,2 & 224 & 63,8 & 351 & 1 & \\
\hline Kurang & 275 & 68,8 & 125 & 31,2 & 400 & $1,90(1,54-2,34)$ & 0,001 \\
\hline \multicolumn{8}{|l|}{ Status Anemia $^{\mathrm{d}}$} \\
\hline Tidak Anemia & 71 & 30,1 & 165 & 69,9 & 236 & 1 & \\
\hline Anemia & 260 & 74,1 & 91 & 25,9 & 351 & $2,46(1,89-3,20)$ & 0,001 \\
\hline \multicolumn{8}{|l|}{ Faktor Pengobatan } \\
\hline \multicolumn{8}{|l|}{ ART } \\
\hline Tidak & 192 & 93,2 & 14 & 6,8 & 206 & 1 & \\
\hline $\mathrm{Ya}$ & 249 & 40,8 & 362 & 59,2 & 611 & $0,44(0,36-0,53)$ & 0,001 \\
\hline \multicolumn{8}{|l|}{ PP INH } \\
\hline Tidak & 417 & 58,1 & 301 & 41,9 & 718 & 1 & \\
\hline $\mathrm{Ya}$ & 24 & 24,2 & 75 & 75,8 & 99 & $0,42(0,28-0,63)$ & 0,001 \\
\hline \multicolumn{8}{|c|}{ Infeksi Oportunis, Faktor Risiko Penularan, Stadium HIV, dan Kadar CD4 } \\
\hline \multicolumn{8}{|l|}{ Infeksi Oportunis $^{e}$} \\
\hline Tidak Ada & 129 & 33,2 & 259 & 66,8 & 388 & 1 & \\
\hline $\mathrm{Ya}$ & 283 & 76,9 & 85 & 23,1 & 368 & $2,31(1,88-2,85)$ & 0,001 \\
\hline \multicolumn{8}{|l|}{ Faktor Risiko $^{f}$} \\
\hline IDU & 80 & 44,7 & 99 & 55,3 & 179 & 1 & \\
\hline Non IDU & 343 & 56,9 & 260 & 43,1 & 603 & $1,27(0,99-1,62)$ & 0,052 \\
\hline \multicolumn{8}{|l|}{ Stadium HIV ${ }^{g}$} \\
\hline 1 dan 2 & 54 & 17,5 & 255 & 82,5 & 309 & 1 & \\
\hline 3 dan 4 & 361 & 77,1 & 107 & 22,9 & 468 & $4,41(3,32-5,88)$ & 0,001 \\
\hline Kadar CD4 & & & & & & & \\
\hline$=500$ & 2 & 8,0 & 23 & 92,0 & 25 & 1 & \\
\hline $350-499$ & 16 & 20,5 & 62 & 79,5 & 78 & $2,56(0,59-11,15)$ & 0,209 \\
\hline $200-349$ & 29 & 27,9 & 75 & 72,1 & 104 & $3,49(0,83-14,61)$ & 0,088 \\
\hline$<200$ & 203 & 68,4 & 94 & 31,6 & 297 & $8,54(2,12-34,39)$ & 0,003 \\
\hline
\end{tabular}

${ }^{a}$ Missing 1, ${ }^{b}$ Missing 10, ${ }^{c}$ Missing 66, ${ }^{d}$ Missing 230, ${ }^{e}$ Missing 61, ${ }^{\mathrm{f}}$ Missing 35, ${ }^{\mathrm{a}}$ Missing 40, ${ }^{\mathrm{h}}$ Missing 313 
Karima, Sudaryo, Kiptiyah, Prediktor Kejadian TB pada ODHA di Salah Satu RS Pemerintah Bogor

stadium HIV 1-2. kelompok dengan kadar CD4 350499 berisiko 2,56 kali (95\% CI: 0,59-11,15) untuk terkena TB dibandingkan pada kelompok dengan kadar CD4 $\geq 500$. Kelompok dengan kadar CD4 200349 berisko 3,49 kali (95\% CI: 0,83-14,61) untuk terkena TB dibandingkan pada kelompok dengan kadar CD4 $\geq 500$. kelompok dengan kadar CD4 < 200 berisiko 8,54 kali (95\% CI: 2,12-34,39) untuk terkena TB dibandingkan pada kelompok dengan kadar CD4 $\geq 500$.

Dalam Tabel. 3, pada responden dengan stadium HIV 1-2, kelompok dengan IO berisiko 6,61 kali (95\% CI: 3,74-11,70) untuk terkena TB dibandingkan pada kelompok tanpa IO. Sedangkan pada responden dengan stadium HIV 3-4 kelompok dengan IO berisko 1,44 kali $(95 \%$ CI: 1,26-1,62) untuk terkena TB dibandingkan pada kelompok tanpa IO.
Pada responden dengan IO (-), kelompok dengan stadium HIV 3-4 berisiko 9,18 kali (95\% CI: 5,36-15,80) untuk terkena TB dibandingkan pada kelompok stadium HIV 1-2. Sedangkan pada responden dengan IO (+), kelompok dengan stadium HIV 3-4 berisiko 1,99 kali $(95 \%$ CI: 1,59-2,48) untuk terkena TB dibandingkan pada kelompok stadium HIV 1-2.

Berdasarkan hasil Tests of Homogeneity of the Odds Ratio sebesar 0,043, menunjukkan bahwa perbedaan 2 PR diantara kedua strata baik berdasarkan stadium HIV maupun status IO menunjukkan perbedaan bermakna sehingga mengindikasikan adanya interaksi antara Stadium HIV dan IO.

Tabel 4 merupakan Final Model dengan 3 variabel yang menunjukkan nilai p bermakna yaitu Kadar $\mathrm{Hb}$, Status IO, dan Stadium HIV, dan adanya interaksi antara stadium HIV IO dan Status IO.

Tabel 3. Analisis Stratifikasi

\begin{tabular}{|c|c|c|c|c|c|c|c|}
\hline \multirow[b]{2}{*}{ Strata } & \multirow[b]{2}{*}{$\begin{array}{l}\text { Eksposure: } \\
\text { Status IO }\end{array}$} & \multicolumn{2}{|c|}{$\mathrm{TB}(+)$} & \multicolumn{2}{|c|}{$\mathrm{TB}(-)$} & \multirow{2}{*}{ Total } & \multirow{2}{*}{ PR (95\% CI) } \\
\hline & & N & $\%$ & $\mathrm{~N}$ & $\%$ & & \\
\hline \multirow{2}{*}{ Stadium HIV 1-2 } & Tidak Ada & 13 & 6,7 & 182 & 93,3 & 195 & 1 \\
\hline & Ada & 41 & 44,1 & 52 & 55,9 & 93 & $6,61(3,74-11,70)$ \\
\hline \multirow{2}{*}{ Stadium HIV 3-4 } & Tidak Ada & 106 & 61,3 & 67 & 38,7 & 173 & 1 \\
\hline & Ada & 227 & 88,0 & 31 & 12,0 & 258 & $1,44(1,26-1,62)$ \\
\hline Strata & $\begin{array}{l}\text { Eksposure: } \\
\text { Stadium HIV }\end{array}$ & & & & & & \\
\hline \multirow{2}{*}{ IO $(-)$} & $1-2$ & 13 & 6,7 & 182 & 93,3 & 195 & 1 \\
\hline & $3-4$ & 106 & 61,3 & 67 & 38,7 & 173 & $9,18(5,36-15,80)$ \\
\hline \multirow{2}{*}{ IO $(+)$} & $1-2$ & 41 & 44,1 & 52 & 55,9 & 93 & 1 \\
\hline & $3-4$ & 227 & 88,0 & 31 & 12,0 & 258 & $1,99(1,59-2,48)$ \\
\hline
\end{tabular}

Tests of Homogeneity of the Odds Ratio $=0,043$

Tabel 4. Model Akhir Multivariat

\begin{tabular}{llrrrrr}
\hline \multirow{2}{*}{ No } & Variabel & \multirow{2}{*}{ B } & \multirow{2}{*}{ Nilai P } & PR & \multicolumn{2}{c}{$95 \%$ CI } \\
& & & & & \multicolumn{2}{c}{ Lower } \\
\hline 1 & Status Anemia & 0,433 & 0,002 & 1,543 & 1,171 & 2,032 \\
2 & Status IO & 1,775 & 0,000 & 5,900 & 2,923 & 11,910 \\
3 & Stadium HIV & 2,174 & 0,000 & 8,794 & 4,547 & 17,005 \\
4 & Stadium HIV*Status IO & $-1,552$ & 0,000 & 0,212 & 0,101 & 0,445 \\
\hline
\end{tabular}

Tabel 5. Kombinasi Nilai PR antara Modifier dan Exposure

\begin{tabular}{ccc}
\hline & $\mathrm{E}(+)$ & $\mathrm{E}(-)$ \\
$\mathrm{IO}(+)$ & $\mathrm{IO}(-)$ \\
\hline $\mathrm{M} \mathrm{(+)}$ & $\mathrm{PR}_{11}=13,2$ & $\mathrm{PR}_{10}=9,19$ \\
(Stadium HIV 3-4) & & \\
M (-) & $\mathrm{PR}_{01}=6,61$ & $\mathrm{PR}_{00}=1$ \\
\hline
\end{tabular}


Untuk melihat apakah terdapat interaksi, dengan menggunakan perhitungan Interaction Contrast Ratio (ICR) dengan ketentuan sebagai berikut:

$\mathrm{ICR}=\mathrm{RR}_{11}-\mathrm{RR}_{10}-\mathrm{RR}{ }_{01}+1$

Pada hasil penelitian ini

$\begin{aligned} \mathrm{ICR} & =\mathrm{RR}_{11}-\mathrm{RR}_{10}-\mathrm{RR}_{-1}+1 \\ & =13,2-9,19-6,61+1 \\ & =-1,6\end{aligned}$

Sehingga ICR $<0$. Artinya ada interaksi biologis subadditivity dalam/di bawah model multiplikatif $\rightarrow$ indikasi interaksi antagonistik atau kompetitif. Hal ini berarti apabila 2 variabel (status IO dan stadium HIV) bergabung, maka akan menimbulkan efek yang saling meniadakan dan bila berdiri sendiri sendiri dapat menimbulkan efek.

\section{Diskusi}

Pengumpulan data berlangsung dari tanggal 12 Mei sampai 7 Juni 2017. Dari pendataan register ART di Poli NAPZA, didapatkan daftar seluruh pasien HIV yang berobat dari tahun 2007-2017. Dari daftar tersebut kemudian dipilih responden yang akan menjadi sampel. Karena dalam penelitian ini metode sampling adalah dengan total sampling, maka seluruh pasien HIV dari tahun 2014-2016 dipilih.

Dalam register ART terdapat informasi yang cukup lengkap mengenai beberapa variabel yaitu hasil skrining TB (dengan tanggalnya), tanggal konfirmasi status HIV, umur, jenis kelamin, pendidikan, jenis pekerjaan, status pernikahan, berat badan, tinggi badan, pemberian ART, Infeksi Oportunis, stadium HIV HIV, dan kadar CD4. Karena ada beberapa variabel yang datanya tidak ada dalam register tersebut, maka dilakukan penelusuran dan konfirmasi data melalui rekam medik.

Desain penelitian ini adalah cross sectional untuk mengetahui faktor apa saja yang berhubungan kejadian TB pada ODHA. Pengukuran exposure dan outcome dilakukan pada saat yang bersamaan. Pada outcome yaitu TB, status TB yang dimaksud adalah status TB yang merupakan hasil skrining pada saat kunjungan pertama ke RS. Sementara pada exposure seperti status gizi (diukur dengan menggunakan IMT), status anemia (diukur dengan menggunakan kadar $\mathrm{Hb}$ ), ART, PP INH, IO, stadium HIV, dan kadar CD4, juga merupakan variabel yang pengukurannya dilakukan pada saat kunjungan pertama ke RS. Idealnya, exposure diukur pada saat sebelum terjadi TB, dan kejadian TB yang dimaksud adalah jenis kejadian TB baru, sehingga kita dapat meminimalisir kelemahan desain penelitian cross sectionaldalam hal temporal time relationship.

Dari total sampel sebanyak 817, beberapa variabel mengalami missing. Missing data tertinggi pada variabel kadar CD4 yaitu 313 subjek, kemudian diikuti oleh kadar Hb sebesar 230 subjek, IMT sebesar 66 subjek, IO sebesar 61 subjek, stadium sebesar 40 subjek, faktor risiko sebesar 35 subjek, status pernikahan sebesar 10 subjek. Sehingga total data yang paling lengkap adalah 374 subjek yang dianalisis pada tahap multivariat. Sedangkan pada tahap univariat dan bivariat menggunakan seluruh data yang tersedia pada masing-masing variabel.

Ketersediaan data dalam hal metode penentuan outcome (status TB) juga terbatas. Sebagian besar status TB dinyatakan dengan skrining yang datanya tersedia di register ART. Setelah dilakukan konfirmasi ke rekam medik, dari 441 kasus TB yang ada, hanya 204 yang mempunyai informasi mengenai metode pemeriksaan TB, yaitu sebagian besar (87,3\%) dengan menggunakan radiologi.

Proporsi kasus TB dalam penelitian ini adalah sebesar 54\% (Tabel 1). Di Indonesia menurut data Kementerian Kesehatan RI hingga akhir Desember 2010 secara kumulatif jumlah kasus AIDS yang dilaporkan berjumlah 24.131 kasus dengan infeksi penyerta terbanyak adalah TB yaitu sebesar 11.835 kasus (49\%). ${ }^{1}$

Dalam penelitian ini kelompok umur > 35 tahun berisiko 1,12 kali (95\% CI: 0,90-1,38) untuk terkena TB dibandingkan pada kelompok umur 15-35 tahun. Hubungan ini tidak signifikan secara statistik (Tabel 2). Melkamu et a/ (2013) dalam penelitian kasus kontrol yang terdiri dari 123 kasus (ODHA dengan TB) dan 246 kontrol (ODHA tanpa TB), menunjukkan bahwa risiko TB lebih besar pada subjek umur > 35 tahun dibandingkan 15-35 tahun (OR=1,31, 95\%CI: 0,84-2,04). ${ }^{9}$ Variabel umur tidak masuk dalam model multivariat, karena sejak tahap analisis bivariat, nilai $p$ menunjukkan hasil yang tidak bermakna.

Dalam penelitian ini, kelompok laki-laki memiliki kecenderungan 0,83 kali (95\% CI: 0,69-1,01) untuk terkena TB dibandingkan pada kelompok perempuan. Hubungan ini tidak signifikan secara statistik (Tabel 2). Dalam penelitian Carvalho et al (2008) dengan menggunakan desain studi kasus kontrol terhadap 274 pasien HIV dewasa, laki-laki mempunyai risiko TB lebih tinggi dibandingkan perempuan untuk menderita TB $(\mathrm{OR}=2,65,95 \% \mathrm{CI}=4,1-15,06)$. Belum diketahui pasti 
apakah hal karena perbedaan perilaku sosial atau pelayanan kesehatan atau keduanya. ${ }^{10}$ Hasil penelitian ini tidak sejalan dengan penelitian-penelitian lain yang sebagian besar menyatakan bahwa laki-laki lebih berisiko TB diabandingkan wanita. Dalam penelitian ini, justru laki-laki mempunyai risiko yang lebih kecil untuk TB dibandingkan wanita. Namun demikian variabel jenis kelamin tidak masuk ke dalam model akhir multivariat.

Berdasarkan Tabel 2, dalam penelitian ini, kelompok pendidikan menengah berisiko 1,42 kali (95\% CI: 1,05-1,93) untuk terkena TB dibandingkan pada kelompok pendidikan tinggi. Sementara kelompok pendidikan rendah berisiko 1,77 kali (95\% CI: 1,16-2,70) dibandingkan pada kelompok pendidikan tinggi. Terlihat bahwa semakin rendah tingkat pendidikan, semakin tinggi risiko TB. Dalam penelitian Carvalho et a/ (2008) dengan menggunakan desain studi kasus kontrol terhadap 274 pasien HIV dewasa yang membagi tingkat pendidikan menjadi < 8 tahun vs $\geq 8$ tahun, pendidikan $<8$ tahun meningkatkan risiko TB dibandindangkan pendidikan $<8$ tahun $(\mathrm{OR}=7,85,95 \% \mathrm{CI}=4,1-15,06) .{ }^{10}$ Tingkat pendidikan dapat mempengaruhi perilaku pasien HIV dan pemahaman tentang tingkat pendidikan yang berisiko dapat membantu program pencegahan infeksi. Tingkat pendidikan mungkin berhubungan dengan kurangnya pendidikan kesehatan dan akses pelayanan kesehatan. Seseorang yang mempunyai tingkat pendidikan formal, cenderung lebih memperhatikan kesehatannya sehingga lebih dapat mengambil keputusan tindakan pencegahan. ${ }^{9}$

Dalam penelitian ini, kelompok yang tidak bekerja memiliki kecenderungan 0,94 kali (95\% CI: 0,76-1,14) untuk terkena TB dibandingkan pada kelompok yang bekerja. Hubungan ini tidak signifikan secara statistik (Tabel 2). Tingkat pendidikan dan pekerjaan menunjukkan hubungan yang signifikan dengan kejadian TB pada pasien HIV. Tingkat pendidikan yang rendah dan tidak bekerja berhubungan dengan semakin tingginya risiko penyakit infeksi. Pekerjaan cenderung juga merefleksikan tingkat pendidikan. Sehingga tingkat pendidikan dan tidak bekerja berperan secara sinergis dalam meningkatkan risiko TB. ${ }^{11}$ Dalam penelitian ini orang yang tidak bekerja justru mepunyai risiko yang lebih rendah untuk terkena TB. Hal ini mungkin disebabkan keterbatasan dalam penelitian ini yaitu informasi mengenai jenis pekerjaan secara detail tidak diambil. Namun variabel ini tidak masuk dalam tahap multivariat karena sejak tahap bivariat tidak menunjukkan perbedaan yang signifikan.

Berdasarkan Tabel 2, dalam penelitian ini, kelompok yang belum menikah memiliki kecenderungan 0,80 kali (95\% CI: 0,66-0,98) untuk terkena TB dibandingkan pada kelompok yang menikah. Sementara kelompok janda/duda memiliki kecenderungan 0,81 kali (95\% CI: 0,56-1,18) dibandingkan pada kelompok yang menikah. Dalam studi yang dilakukan oleh Alberto et al (2015) dengan menggunakan desain studi cross sectiona/ pada 300 pasien HIV menunjukkan bahwa risiko TB dari subjek yang tidak menikah lebih besar daripada subjek yang menikah (OR = 1,96, 95\%CI: 1,01-3,79). Risiko TB paru juga meningkat pada subjek yang bercerai $(\mathrm{OR}=1,48$, 95\% CI: 0,54-4,03). ${ }^{12}$ Kibret et a/ (2013) dalam studinya dengan menggunakan desain kasus kontrol yang terdiri dari 204 kasus (ODHA dewasa yang mengalami TB setelah ARV) dan 409 kontrol (ODHA dewasa yang tidak menderita TB setelah ART) menemukan bahwa pada hasil analisis multivariat, status pernikahan cerai/ janda lebih kecil risikonya untuk menjadi TB dibandingkan subjek yang menikah $(\mathrm{OR}=0,36,95 \%$ CI: 0,16-0,82). Hal ini mungkin disebabkan karena subjek yang single cenderung lebih muda dan mempunyai gaya hidup yang berbeda terutama pada laki-laki yang sering berpindah untuk mencari kerja. ${ }^{13}$

Dalam penelitian ini, kelompok dengan IMT kurang berisiko 1,90 kali (95\% CI: 1,54-2,34) untuk terkena TB dibandingkan pada kelompok dengan IMT baik. Hubungan ini signifikan secara statistik (Tabel 2). Melkamu et al (2013) dalam penelitian kasus kontrol yang terdiri dari 123 kasus (ODHA dengan TB) dan 246 kontrol (ODHA tanpa TB), menunjukkan bahwa dalam analisis multivariat, risiko TB lebih besar pada subjek dengan IMT < 18,5 kg/m2 dibandingkan $\geq 18,5$ kg/m2 (OR=3,87, 95\%CI: 2,18-6,87). ${ }^{9}$ Gizi kurang dapat melemahkan tingkat imunitas dan meningkatkan reaktivasi TB laten. Karena desain studi dalam penelitian ini adalah cross sectional, tampaknya besarnya nilai PR masih mengalami overestimate karena status IMT dan status TB diukur pada saat yang bersamaan, sehingga mungkin saja IMT yang rendah merupakan konsekuensi dari adanya TB.

Dalam penelitian ini, kelompok anemia berisiko 2,46 kali (95\% CI: 1,89-3,20) untuk terkena TB dibandingkan pada kelompok yang tidak anemia. Hubungan ini signifikan secara statistik (Tabel 2). Pada analisis multivariat (final mode) variabel status anemia masuk sebagai salah satu prediktor kejadian TB (Tabel 
4). dengan nilai $P R=1,54,95 \%$ CI: $1,17-12,03)$. Hasil penelitian ini sejalan dengan penelitian yang dilakukan oleh Taha et a/(2011) dengan desain studi kasus kontrol terhadap 162 kasus dan 647 kontrol menunjukkan bahwa dalam analisis multivariat, kadar $\mathrm{Hb}<10 \mathrm{mg} / \mathrm{dl}$ lebih berisiko untuk terkena TB dibandingkan dibandingkan kadar $\mathrm{Hb} \geq 12,5 \mathrm{mg} / \mathrm{dl}(\mathrm{OR}=2,8,95 \% \mathrm{CI}$ : 1,5-5,2). ${ }^{14}$ Sedangkan kadar Hb 10-12,49 mg/dl lebih berisiko untuk terkena TB dibandingkan dibandingkan kadar $\mathrm{Hb} \geq 12,5 \mathrm{mg} / \mathrm{dl}(\mathrm{OR}=1,4,95 \% \mathrm{CI}: 0,8-2,4) .{ }^{14}$

Dalam penelitian ini pemberian ART dan PP INH menunjukkan efek protektif tehadap TB (Tabel 2) dengan nilai PR masing-masing adalah $\mathrm{PR}=0,44(95 \%$ CI: 0,36-0,53) dan PR=0,42 (95\% CI: 0,28-0,63). Penelitian yang dilakukan oleh Taha et al (2011) dengan desain studi kasus kontrol terhadap 162 kasus dan 647 kontrol menunjukkan bahwa dalam analisis multivariat, tidak diberi ART dapat meningkatkan risiko terkena TB (OR=3,1, 95\% CI: 1,9-4,9). ${ }^{14}$ Pemberian IPT dapat menurunkan mycobacterium load dan menurunkan progresi dari TB laten menjadi TB aktif. Peningkatan mycobacterium loadjuga dipengaruhi oleh penurunan yang progresif dari respon sel $T$ terhadap mycobacterium spesific. ${ }^{14}$

Dalam penelitian ini kelompok yang mempunyai IO berisiko 2,31 kali (95\% CI: 1,88-2,85) untuk terkena TB dibandingkan pada kelompok yang tidak mempunyai IO. Hubungan ini signifikan secara statistik (Tabel 2).Pada analisis multivariat (final mode) variabel infeksi oportunis masuk sebagai salah satu prediktor kejadian TB (Tabel 4) dengan nilai $P R=5,90,95 \%$ CI: 2,9-11,9. Kibret et al (2013) dalam studinya dengan menggunakan desain kasus kontrol yang terdiri dari 204 kasus (ODHA dewasa yang mengalami TB setelah ARV) dan 409 kontrol (ODHA dewasa yang tidak menderita TB setelah ART) menemukan bahwa pada hasil analisis multivariat, adanya infeksi oportunis meningkatkan risiko TB $(\mathrm{OR}=$ 4,80, 95\% CI: 3,29-7,00). ${ }^{13}$

Dalam penelitian ini, kelompok dengan faktor risiko non IDU berisiko 1,27 kali (95\% CI: 0,99-1,62) untuk terkena TB dibandingkan pada kelompok dengan faktor risiko IDU. Hubungan ini tidak signifikan secara statistik (Tabel 2). Agbaji et a/(2013) menemukan risiko TB paru pada transmisi melalui heteroseksual lebih kecil dibandingan transmisi melalui transfusi darah (OR=0,41, 95\% CI: 0,04-3,89). ${ }^{15}$

Dalam penelitian ini, kelompok dengan stadium HIV 3-4, berisiko 4,41 kali (95\% CI: 3,32-5,88) untuk terkena TB dibandingkan pada kelompok dengan stadium HIV 1-2. Hubungan ini signifikan secara statistik (Tabel 2). Pada analisis multivariat (final mode) variabel stadium HIV masuk sebagai salah satu prediktor kejadian TB (Tabel 4) dengan nilai PR= 8,79, 95\% CI: 4,55-17,00). Agbaji et al (2013) menemukan bahwa stadium klinis 3-4 meningkatkan risiko TB paru dibanandingkan stadium klinis 1-2 (OR=3,54, 95\% CI: 0,72-17,42). ${ }^{15}$ Hasil penelitian ini pada umunya sejalan dengan penelitian-penelitian lain yang menyatakan bahwa semakin tinggi stadium HIV maka semakin tinggi risiko TB.

Berdasarkan Tabel 2, dalam penelitian ini, kelompok dengan kadar CD4 350-499 berisiko 2,56 kali (95\% CI: 0,59-11,15) untuk terkena TB dibandingkan pada kelompok dengan kadar CD4 $\geq 500$. Kelompok dengan kadar CD4 200-349 berisko 3,49 kali (95\% CI: 0,83-14,61) untuk terkena TB dibandingkan pada kelompok dengan kadar CD4 $\geq 500$. kelompok dengan kadar CD4 < 200 berisiko 8,54 kali (95\% CI: 2,12-34,39) untuk terkena TB dibandingkan pada kelompok dengan kadar CD4 $\geq 500$. Semakin rendah kadar CD4, maka semakin tinggi risiko TB pada ODHA. Dari nilai PR beberapa kategori kadar CD4, menunjukkan adanya dose respons relationship, yaitu semakin berkurangnya kadar CD4, proporsi ditemukannya TB akan meningkat. Dalam penelitian Agbaji et a/(2013), dengan studi cross sectiona/terhadap 218 pasien HIV menemukan bahwa kadar CD4 > 100 per mm3 menurunkan risiko TB paru dibandingkan kadar $C D 4 \leq 100$ per $\mathrm{mm}^{3}(\mathrm{OR}=0,15,95 \%$ CI: 0,05-0,49). ${ }^{15}$ Infeksi kuman TB dapat meningkatkan viral load yang dapat menyebabkan terjadinya imunosupresi pada host dan meningkatkan virulensi kuman TB. Kondisi imunosupresi dapat meningkatkan kemungkinan kuman TB yang dorman mengalami reaktivasi. Viral loadyang tinggi meningkatkan progresi penyakit. ${ }^{10}$

Pada analisis stratifikasi (Tabel 3) antara infeksi oportunis dengan stadium, terlihat ada perbedaan besarnya PR yang mengindikasikan interaksi yaitu apabila strata dilihat berdasarkan stadium, pada responden dengan stadium HIV 1-2, kelompok dengan IO berisiko 6,61 kali (95\% CI: 3,74-11,70) untuk terkena TB dibandingkan pada kelompok tanpa IO. Pada responden dengan stadium HIV 3-4, kelompok dengan IO berisko 1,44 kali (95\% CI: 1,26-1,62) untuk terkena TB dibandingkan pada kelompok tanpa IO.

Sedangkan apabila strata dilihat berdasarkan 
status $\mathrm{IO}$, pada responden dengan IO (-), kelompok dengan stadium HIV 3-4 berisiko 9,18 kali (95\% CI: 5,3615,80) untuk terkena TB dibandingkan pada kelompok stadium HIV 1-2. Pada responden dengan IO (+), kelompok dengan stadium HIV 3-4 berisiko 1,99 kali (95\% CI: 1,59-2,48) untuk terkena TB dibandingkan pada kelompok stadium HIV 1-2. Berdasarkan hasil Tests of Homogeneity of the Odds Ratio sebesar 0,043, menunjukkan bahwa perbedaan 2 PR diantara kedua strata stadium menunjukkan perbedaan bermakna sehingga mengindikasikan adanya interaksi antara Stadium dan $\mathrm{IO}$.

Hasil analisis multivariat (Tabel 4) menunjukkan adanya peningkatan risiko TB pada kelompok dengan anemia (PR=1,54, 95\% CI: 1,17-2,03) dibandingkan kelompok tanpa anemia, adanya status IO ( $P R=5,9,95 \%$ CI: 2,92-11,91) dibandingkan kelompok tanpa IO, stadium HIV 3-4 (PR=8,79, 95\% CI: 4,54-17,00) dibandingkan stadium HIV 1-2.

Selain itu, dalam model akhir ditemukan adanya interaksi antara variabel stadium HIV dan status IO. Dari kedua variabel yang berinteraksi yaitu stadium (stadium 1-2 vs 3-4) dan status IO (tidak vs ya), kemudian diidentifikasi jenis interaksi yang terjadi dengan menggunakan perbandingan nilai PR11, PR $\neg 01$, PR10, PRO0 (Tabel 5).

Dari hasil perhitungan Interaction Contrast Ratio (ICR), ditemukan bahwa nilai ICR pada variabel yang berinteraksi adalah $<1$, Artinya ada interaksi biologis subadditivity dalam/di bawah model multiplikatif, indikasi interaksi antagonistik atau kompetitif.

Hal ini berarti apabila 2 variabel (status IO dan stadium HIV) bergabung, maka akan menimbukan efek yang saling meniadakan dan bila berdiri sendiri sendiri dapat menimbulkan efek. Dalam penelitian ini tampaknya stadium HIV memiliki efek yang lebih kuat dalam kejadian TB karena pada stadium HIV awal (1-2) dan status IO positif, efeknya lebih rendah ( $P R=6,61$, 95\% CI: 3,54-12,34), dibandingkan pada stadium HIV HIV akhir (3-4) dan status IO nya negatif ( $P R=9,19$, 95\% CI: 5,17-16,35).

Penelitian Crowe et al (1991), 5 jenis infeksi oportunistik yang muncul berdasarkan penurunan kadar CD4 adalah ${ }^{16}$

a. CD4 $>500 / \mathrm{mm} 3 \rightarrow$ asymptomatic infection

b. CD4 250-500/mm3 $\rightarrow$ Kandidiasis oral dan TB

c. CD4 150-200 $\rightarrow$ Kaposi sarcoma, lymphoma, dan cryptosporidiosis d. CD4 75-125/mm3 $\rightarrow$ Pneumocystis carinii, pneumonitis, disseminated Mycobacterium avium complex, herpes simplex, toxoplasmosis, cryptococcosis, dan esophageal candidiasis

e. $\quad$ CD4 $<50 / \mathrm{mm} 3 \rightarrow$ cytomegalovirus retinitis

Infeksi oportunistik yang muncul pada masa awal adalah kandidiasis oral dan TB. Dalam penelitian ini, apabila dibandingkan dengan kelompok referens berupa stadium 1-2 dan IO (-), PR pada kelompok stadium 3-4 dan IO (-) yaitu 9,19 (95\% CI: 5,17-16,35). Sementara PR pada kelompok stadium 1-2 dan IO (+) yaitu 6,61 (95\% CI: 3,54-12,34). Dalam penelitian ini tampaknya stadium HIV memiliki efek yang lebih kuat dalam kejadian TB

Bias informasi yang mungkin terjadi pada pengukuran status TB yaitu status TB ditentukan berdasarkan data register ART di Poli NAPZA. Dalam data tersebut hanya ada keterangan hasil skrining TB apakah positif $(+)$ atau $(-)$, tidak ada rincian data mengenai metode penentuannya. Hal ini akan menimbulkan potensi bias informasi. Upaya yang dilakukan untuk mengkonfirmasi metode pemeriksaan TB adalah dengan memeriksa rekam medik. Dari 817 jumlah sampel hanya 204 yang memuat informasi mengenai metode pemeriksaan TB.

Dari total 856 pasien HIV yang akan diikutkan dalam penelitian, terdapat 39 subjek yang tidak memiliki data mengenai status TB. Sehingga 817 pasien HIV terpilih untuk dianalisis. Namun dari 817 pasien HIV tersebut, terjadi missing data pada beberapa variabel dengan jumlah yang berbeda-beda. Hal ini menimbulkan potensi adanya bias seleksi.

Peran chancetampaknya minimal kecuali pada beberapa variabel yang menunjukkan rentang Confidence Interva/cukup lebar pada hubungan antara kadar CD4 dan TB (Tabel 2). Hal ini tampaknya disebabkan karena pada variabel tersebut terdapat missing data yang cukup banyak.

\section{Simpulan dan Saran}

Kesimpulan dalam penelitian ini antara lain proporsi TB pada ODHA tahun 2014-2016 adalah sebesar 54\%, prediktor kejadian TB pada ODHA adalah status anemia, status IO, dan stadium HIV dengan nilai PR sebagai berikut: anemia vs tidak anemia $(P R=1,54$, 95\% CI: 1,17-2,03), status IO (ya) vs status IO (tidak) ( $P R=5,9,95 \%$ CI: 2,92-11,91), stadium HIV 3-4 vs stadium HIV 1-2 (PR=8,794, 95\% CI: 4,54-17,00), dan ada interaksi antara stadium HIV dan status IO. 
Saran bagi RS antara lain perlu perhatian khusus kepada ODHA dengan anemia, infeksi oportunis, dan stadium HIV lanjut (3-4), perlu perhatian khusus kepada ODHA dengan stadium HIV awal (1-2) tetapi disertai dengan infeksi oportunis, perlu pencatatan yang lebih lengkap mengenai status TB dari segi jenis pasien TB (kambuh, lama, atau kasus baru), metode pemeriksaan TB (radiologi, dahak, atau gejala klinis). Saran bagi peneliti selanjutnya antara lain perlu mempersempit kriteria kasus TB menjadi hanya kasus baru saja agar meminimalisir temporal ambiguity, perlu memperhitungkan faktor lain yang penting seperti kepatuhan pengobatan ART, PP INH, dan menggunakan desain penelitian yang lebih baik dalam hal temporal relationship seperti kohort. Saran bagi masyarakat antara lain perlu kewaspadaan bagi ODHA mengenai perkembangan penyakitnya yaitu apabila mengalami anemia, infeksi oportunis mulai dari stadium HIV awal (1-2), dan jika sudah memasuki stadium HIV akhir (3-4) agar selalu memantau, menjaga, dan mempertahankan status kesehatannya ke pelayanan kesehatan.

\section{Referensi}

1. Kementerian Kesehatan Republik Indonesia. Pedoman Nasional Pelayanan Kedokteran Tata Laksana Tuberkulosis. 2012. April 11, 2016. http://spiritia.orid/dokumen/juknistbhiv2013.pdf

2. WHO. Global Tuberculosis Report 2015. World Health Organization. 2015. May 22, 2016. http://apps.who.int/iris/ bitstream/10665/191102/1/9789241565059_eng.pdf

3. Narain P, Lo YR. Epidemiology of HIV-TB in Asia. Indian J Med Res. 2004; 120, pp 277-289. March 8, 2016. https:/ / search.proquest.com/openview/ d 8550 ddc 0443 b 9 a $1 \mathrm{ff} 74$ f 278 e edf $991 \mathrm{c} /$ 1 ? pqorigsite $=$ gscholar $\& c b l=37533$

4. Padmapriyadarsini C, Narendran G, Swaminathan S. Diagnosis \& treatment of tuberculosis in HIV co-infected patients. Indian Journal of Medical Research. 2011; 134(12), pp.850865. January 22, 2017 http://www.embase.com/search/ results?subaction=viewrecord\&from=export\&id=L364191264\%0Ahttp:/ /icmr.nic.in/ijmr/2011/december/1209.pdf.

5. Uyainah A. 2009. TB/HIV coinfection. June 5. 2016. http:/ /www. healthefoundation.eu/blobs/hiv/TBHIV_Peduli_AIDS_131109.pdf

6. Putri AJ, Darwin, Efrida. Pola infeksi oportunistik yang menyebabkan kematian pada penyandang AIDS di RS Dr. M. Djamil Padang tahun 2010-2012. Jurnal Kesehatan Andalas. 2015; 4(1), pp.10-16. June 15, 2016. http:// jurnal.fk.unand.ac.id/index.php/jka/article/view/174

7. Kelsey JL, Whittemore AS, Evans AS, Thompson WD. Methods in Observational Epidemiology. 1996. New York: Oxford University Press.
8. SPSS Inc. SPSS for Windows, Version 22.0. Chicago, SPSS Inc.

9. Melkamu H, Seyoum B, Dessie Y. Determinants of tuberculosis infection among adult HIV positives attending clinical care in Western Ethiopia?: a case-control study. Hindawi Publishing Corporation, 2013. April 10, 2016. https://www.hindawi.com/journals/art/2013/279876/

10. Carvalho ACC, Nunes ZB, Martins M, Araujo ROC, Comelli M, Marinoni A, Kritski AL. Clinical Presentation and Survival of Smear-positive Pulmonary Tuberculosis Patients of a University General Hospital in a Developing Country. Mem Inst Oswaldo Cruz. 2002; 97(December), pp.1225-1230. March 8, 2017. https://www.health.ny.gov/publications/ 9689.pdf

11. Awadalla H, El-Samani F Soghaier MA, Makki M. Risk factors associated with the development of tuberculosis among HIV-infected patients in Khartoum in 2010. AIMS Public Health. 2015;2 (December), pp.784-792. April 10, 2016. http://www.aimspress.com/article/10.3934/ publichealth.2015.4.784/fulltext.html

12. Alberto F, Rodriguez $\mathrm{H}$, Agbo, SO. An assessment of the risk factors for pulmonary tuberculosis among adult patients suffering from human immunodeficiency virus attending the Wellness Clinic at Themba Hospital. South African Family Practice. 2015; 6190, pp.1-6. March 19, 2017. http://dx.doi.org/10.1080/20786190.2014.978105.

13. Kibret KT, Yalew AW, Belaineh BG, Asres MM. Determinant factors associated with occurrence of tuberculosis among adult people living with HIV after antiretroviral treatment initiation in Addis Ababa, Ethiopia?: a case control study. Plos One. 2013; 8(5), pp.23-27. April 10, 2016. http:// journals.plos.org/plosone/article?id=10.1371/ journal.pone.0064488

14. Taha M, Deribew A, Tessema F, Assegid S, Duchateau L, Colebunders R. Risk factors of active tuberculosis in people living with HIV/AIDS in Southwest Ethiopia: a case control study. Ethiop J Health Sci. 2011; 21(22), pp.131-139. April 10, 2016. https://www.ncbi.nlm.nih.gov/pubmed/ 22434992

15. Agbaji O, Ebonyi AO, Meloni ST, Anejo-Okopi JA, Akanbi $\mathrm{MO}$, Oguche $\mathrm{S}$, et al. AIDS \& clinical factors associated with pulmonary tuberculosis-HIV co-infection in Treatment-Naive Adults in Jos, North Central Nigeria. J AIDS Clin Res. 2013; 4(7). March 8, 2017. http:// dspace.unijos.edu.ng/jspui/handle/123456789/564

16. Crowe SM, Carlin JB, Lucas CR, Hoy JF. Predictive value of CD4 lymphocyte numbers for the development of opportunistic and malignancies in HIV-infected persons. J Acquir Immune Defic Syndr. 1991. June 15, 2017. https:/ /www.ncbi.nlm.nih.gov/pubmed/1677419Alemu, Y.M., Awoke, W. \& Wilder-Smith, A., 2016. Determinants for tuberculosis in HIV-infected adults in Northwest Ethiopia: a multicentre case-control study. BMJ open, 6(4), p.e009058. March 8, 2017. https://www.ncbi.nlm.nih.gov/ pmc/articles/PMC4838743/ 